\title{
Population of phosphate solubilizing bacteria in the liquid organic fertilizer created from palm oil bunches and pineapple rhizome
}

\author{
DERMIYATI ${ }^{1, \bullet}$, RADIX SUHARJO ${ }^{2}$, MARELI TELAUMBANUA ${ }^{3}$, YEYEN ILMIASARI ${ }^{4}$, RULLY YOSITA $^{4}$, \\ RAHMA MEULY ANNISA ${ }^{5}$, ANGGI WINANDA SARI ${ }^{5}$, ANIS PUJI ANDAYANI ${ }^{5}$, DWI MARSENTA YULIANTI \\ ${ }^{1}$ Department of Soil Science, Faculty of Agriculture, Universitas Lampung. Jl. Prof. Sumantri Brojonegoro, Bandar Lampung 35145, Lampung, \\ Indonesia. Tel.: +62- 721-701609, Fax.: +62-721-702767, `email: dermiyati.1963@fp.unila.ac.id \\ ${ }^{2}$ Department of Plant Protection, Faculty of Agriculture, Universitas Lampung. J1. Prof. Sumantri Brojonegoro, Bandar Lampung 35145, Lampung, \\ Indonesia \\ ${ }^{3}$ Department of Agricultural Engineering, Faculty of Agriculture, Universitas Lampung. Jl. Prof. Sumantri Brojonegoro, Bandar Lampung 35145, \\ Lampung, Indonesia \\ ${ }^{4}$ Agronomy Graduate Program, Universitas Lampung. Jl. Prof. Sumantri Brojonegoro, Bandar Lampung 35145, Lampung, Indonesia \\ ${ }^{5}$ Department of Agrotechnology, Faculty of Agriculture, Universitas Lampung. J1. Prof. Sumantri Brojonegoro, Bandar Lampung 35145, Lampung, \\ Indonesia
}

Manuscript received: 13 October 2019. Revision accepted: 25 October 2019.

\begin{abstract}
Dermiyati, Suharjo R, Telaumbanua M, Ilmiasari Y, Yosita R, Annisa RM, Sari AW, Andayani AP, Yulianti DM. 2019. Population of phosphate solubilizing bacteria in the liquid organic fertilizer created from palm oil bunches and pineapple rhizome. Biodiversitas 20: 3315-3321. Palm oil bunches and pineapple rhizomes are abundant in Indonesia, especially in Lampung Province due to widespread agro-industrial company and they are potential to be used as sources for liquid organic fertilizer. This study was aimed to reveal microbial population within liquid organic fertilizer (LF) which was developed from palm oil bunches (PB) and pineapple rhizome (PR) and their role as phosphate solubilizing bacteria (PSB). The capability to solubilize phosphate was recorded from the clear zone area around the bacterial colony which was cultivated on Pikovskaya's agar medium. The LF was prepared in three kinds of conditions, namely aerobic, anaerobic, and facultative an aerobic. Isolation was performed every 3 days until 24 days after incubations. The results showed that microbial population in the LF from PR was significantly higher than those developed from PB. Totally, 791 bacterial isolates were obtained from the LF; 490 isolates were achieved from PR (153 isolates from aerobic, 188 isolates from facultative anaerobic, 149 from anaerobic conditions) and 301 isolates were collected from PB (96 isolates from aerobic, 112 isolates from facultative anaerobic, 93 isolates from anaerobic conditions). In the case of isolates that were gained from PB, 166 isolates (55.15\%) showed capability to degrade phosphate and 135 isolates (44.85\%) did not show any capability as PSB. As for isolates obtained from PR, 269 isolates $(54.90 \%)$ had capability to solubilize phosphate, meanwhile, the other 221 isolates $(45.10 \%)$ did not show any capability to solubilize phosphate. Among166 isolates of PSB from PB, 60 isolates had very low capability, 55 isolates had low capability, 34 isolates had medium capability, 10 isolates had high capability and only 7 isolates had very high capability. Meanwhile, from 269 isolates of PSB obtained from PR, 135 isolates had very low capability to solubilize phosphate, 84 isolates had low capability to solubilize phosphate, 32 had medium capability to solubilize phosphate, 14 isolates had high capability to solubilize phos phate and 4 isolates produced very high capability as PSB. In total, 11 chosen isolates were selected from LF developed from both PB (7 isolates) and PR (4 isolates). Therefore, palm oil bunches and pineapple rhizomes contained PSB that can be used as LF.
\end{abstract}

Keywords: Aerobic and anaerobic bacteria, population, biodiversity, liquid organic fertilizer, palm oil bunches, pineapple rhizomes

\section{INTRODUCTION}

Lampung Province has many potential agro-industries that play an important role in the economic growth of Indonesia such as sugar, palm oil, rubber, tapioca, monosodium glutamate (MSG), ethanol, fruit processing, and canning shrimp. However, agro-industries also produce various kinds of organic waste in large quantities that are harmful to the environment (Muralikrishna and Manickam 2017).

Palm oil bunches waste become an important problem in palm oil plantation worldwide. A large amount of this waste $\left(220-230 \mathrm{~kg}^{-1}\right.$ of fresh palm oil fruit) and its difficulties to be degraded are the main reasons. Some companies are doing nothing on this waste and the consequence is that this waste becomes suitable host of some palm oil pest insects and pathogens, especially Oryctes rhinoceros and Ganoderma boninense (Salmina 2016).

On the other hand, pineapple rhizomes are also important waste found in pineapple plantations. This waste cause problems especially on the planting seasons. If these pineapple rhizomes are not degrading immediately, the stump is still alive and it will grow and occupy the field that will be used to cultivate the seedling. The other problem is that if this waste is laid on the field, it will be host of some pest insects and pathogens (de Kogel 2019).

Converting these both waste into beneficial material is now still being investigated and improved and one of which is converting this waste into liquid organic fertilizer. Liquid organic fertilizer is fertilizer which was made from fermented organic materials such as rice, compost, plant 
materials including palm oil bunches and pineapple rhizomes. This fermented fertilizer consists of bacterial isolates which have various capacities such as phosphate solubilizing bacteria (PSB), chitin degrading bacteria, antagonist and plant growth promoter (Alori et al. 2017; Ingle and Padole 2017; Rina et al. 2017). This fertilizer also can be used as bioactivator to decompose other organic materials (Rina et al. 2017).

Phosphate-solubilizing bacteria play a vital role in $\mathrm{P}$ solubilization by producing organic acids. The application of organic acids along with PSB enhanced soluble P in the soil solution, improved root growth, and increased plant biomass of aerobic rice seedlings without affecting soil $\mathrm{pH}$ (Biswas et al. 2000). Several bacteria belonging to genera Pseudomonas, Bacillus, Rhizobium, and Enterobacter and also some fungi like Penicillium and Aspergillus are capable of solubilizing P (Whitelaw 2000) and the bacteria like Bacillus megaterium, B. circulans, B. subtilis, $B$. polymyxa, $B$. sircalmous, Pseudomonas striata, and Enterobacter are often most referred as PSB (Subba Rao 1993; Kucey et al. 1989). Moreover, PSB can solubilize the fixed phosphorus in the soil because of their capacity to convert inorganic unavailable phosphorus form to soluble forms $\mathrm{HPO}_{4}{ }^{2-}$ and $\mathrm{H}_{2} \mathrm{PO}_{4}{ }^{-}$through the process of organic acid production, chelation and ion exchange reactions and make them available to plants. Therefore, the use of PSB in agricultural practice would reduce the high cost of manufacturing phosphate fertilizers as well as would also mobilize insoluble phosphate in the fertilizers and soils (Zaidi et al. 2010; Banerjee et al. 2010).

This research was performed in order to examine bacterial population and to do a screening of PSB within liquid fertilizer developed from palm oil bunches and pineapple rhizomes. The chosen PSB will further explore to know their possibilities to be used as bioactivator to decompose other organic materials, especially palm oil bunches and pineapple rhizomes.

\section{MATERIALS AND METHODS}

\section{Development of liquid organic fertilizer (LF)}

Liquid organic fertilizer (LF) was developed using two basic ingredients (palm oil bunches and pineapple rhizomes) in three conditions, namely aerobic, anaerobic, and facultative anaerobic. The process of making LF was performed using reactor machine developed by Telaumbanuwa et al. (2019). Pineapple rhizomes were taken from Perseroan Terbatas (PT) Great Giant Pineapple Co., Terbanggi Besar, Central Lampung, Lampung Province (Figure 1.A), while palm oil bunches were taken from PT Perkebunan Nusantara (PTPN) VII, Rejosari, Natar, Lampung Province (Figure 1.B).

\section{LF from palm oil bunches}

Palm oil bunches $(2.5 \mathrm{~kg})$ were cut into small pieces and put inside the reactor machine. The other ingredients, namely palm sugar $(0.5 \mathrm{~kg})$, coconut water $(2.5 \mathrm{~L})$, and water of washing rice $(2.5 \mathrm{~L})$ were also put into machine. The sample of LF was collected from the machine 9 times in each condition every 3 days after placing the materials.

\section{LF from pineapple rhizomes}

Pineapple rhizomes $(5 \mathrm{~kg})$ were cut into small pieces $(2 \times 2 \mathrm{~cm})$ and placed into reactor machine and followed by palm sugar $(1 \mathrm{~kg})$, coconut water $(5 \mathrm{~L})$ and water of washing rice $(5 \mathrm{~L})$. The sample of LF was collected 9 times from the machine in each condition every 3 days after placing the material.
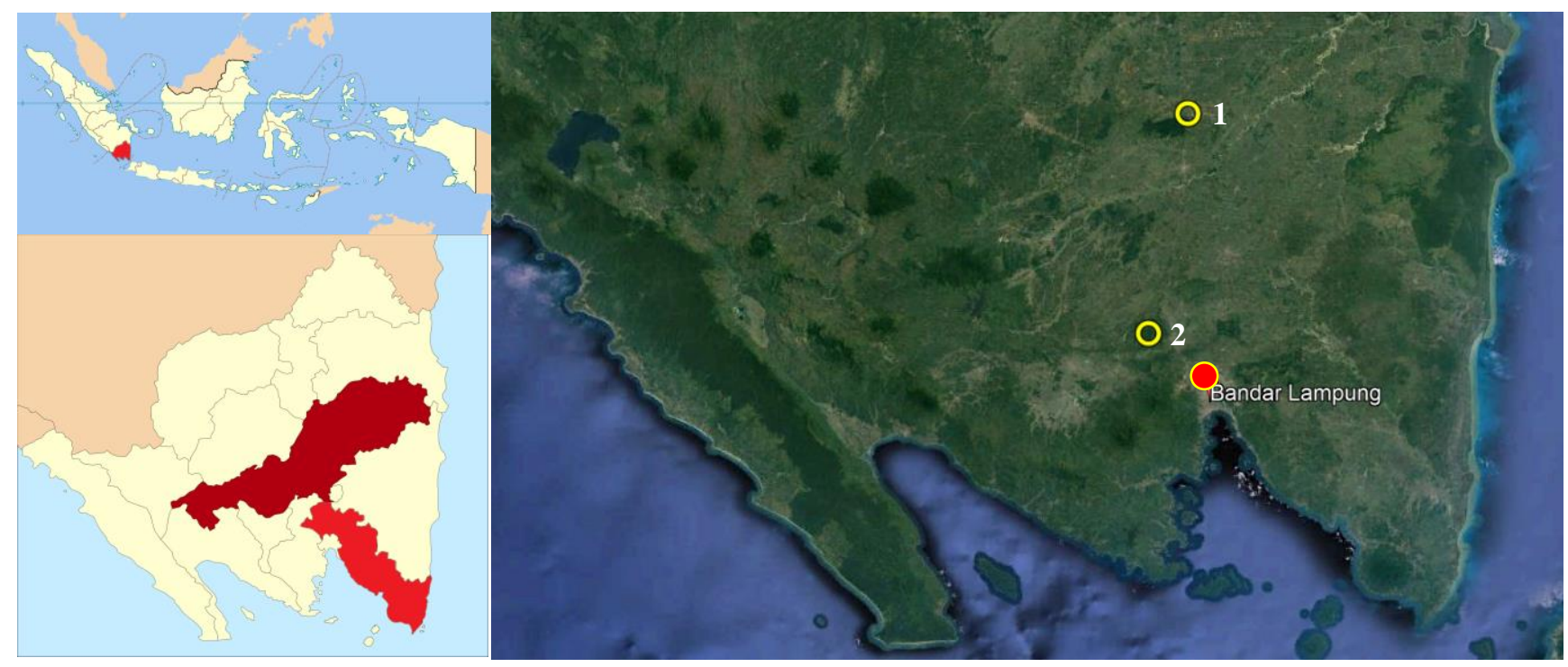

Figure 1. Sampling location where organic materials are taken for this study in Lampung Province, Indonesia: 1. PT Great Giant Pineapple Co. at Terbanggi Besar, Central Lampung, Lampung Province; 2. PTPN VII at Rejosari, Natar, Lampung Province (Source: Google Map \& Wikipedia) 


\section{Bacterial isolation and propagation}

Bacterial isolation

All the collected samples were diluted at $10^{-10}, 10^{-12}$ and $10^{-14}$. From each dilution series, $50 \mu \mathrm{l}$ and $100 \mu \mathrm{l}$ of the suspension were spread onto sterile plastic petri dish (diameter $9 \mathrm{~cm}$ ) containing Plate Count Agar Peptone (PCAP) media (plate count agar (PCA; OXOID ${ }^{\circledR}$; England) $17.4 \mathrm{~g}$, peptone (OXOID ${ }^{\circledR}$; England) $2.5 \mathrm{~g}$, Agar $2 \mathrm{~g}$ and $1000 \mathrm{~mL}$ distillate water). Observation was performed every day for 7 days on the total bacterial colonies which were emerged.

\section{Bacterial propagation}

The emerging bacteria were purified by placing onto sterile plastic petridish (diameter $9 \mathrm{~cm}$ ) containing Yeast Peptone Agar (YPA) media peptone (OXOID ${ }^{\circledR}$, England) $10 \mathrm{~g}$, Yeast Extract (HIMEDIA ${ }^{\circledR}$; India) $5 \mathrm{~g}$, agar $20 \mathrm{~g}$, and $1000 \mathrm{~mL}$ distillate water). For further analysis, the bacteria were streak into Potato Peptone Glucose Agar (PPGA) slant media.

\section{Capability as phosphate solubilizing bacteria}

Investigation was performed by placing the bacteria onto sterile plastic Petri dish containing Pikovskaya (HIMEDIA $^{\circledR}$; India) (Nguyen et al. 1992; Seshadri et al. 2002). Each Petri dish consists of 3 bacterial isolates. Observation was conducted every day for 7 days on the clear zone area around the bacterial colony. The clear zone area was calculated using millimeter block. This clear zone shows capability of the bacterial isolates to solubilize phosphate. Wider clear zone area created by the colony shows higher capability to solubilize phosphate. In this study, capability to solubilize phosphate was categorised as index phosphate solubilization which was divided into 5 level, namely very low capability (clear zone area is in the range of $0.1-1.0$ ), low capability (clear zone area is in the range of 1.01-2.0), medium capability (clear zone area is in the range of 2.01-3.0), high capability (clear zone area is in the range of 3.01 to 4.0 ) and very high capability (clear zone area is more than 4.0) (Matos et al. 2017).

\section{RESULTS AND DISCUSSION}

Three conditions of making liquid organic fertilizer (LF) were used in this study. Those were aerobic, anaerobic and facultative anaerobic conditions. Two kinds of material were used as basic ingredients, namely palm oil bunches and pineapple rhizomes. The LF processing was made using a machine developed by Telaumbanuwa et al. (2019) which created the aerobic, anaerobic, or facultative anaerobic conditions. The LF was further investigated on its bacterial population and its capability to solubilize phosphate.

\section{Microbial population within liquid organic fertilizer (LF)}

Microbial population in the LF was counted by the amount of bacterial grown in the Plate Count Agar Peptone (PCAP) media which was modified from PCA media (Atlas 2010). The results showed that bacterial population within liquid organic fertilizer in each aerobic, anaerobic, facultative anaerobic conditions of making LF by using reactor machine developed by Telaumbanua et al. (2019). In the case of LF developed from palm oil bunches, at 24 days after processing, the highest population was obtained



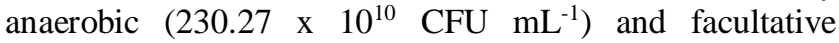
anaerobic $\left(175.13 \times 10^{10} \mathrm{CFU} \mathrm{mL}^{-1}\right)$ conditions. It appeared that in the aerobic condition, the bacteria will grow and replicate faster than in the anaerobic and the facultative anaerobic conditions (Fig 2a). This was likely that LF developed from palm oil bunches was dominated by aerobic bacteria. Aerobic bacteria are able to use oxygen, whereas anaerobic bacteria can sustain itself without the presence of oxygen.



A

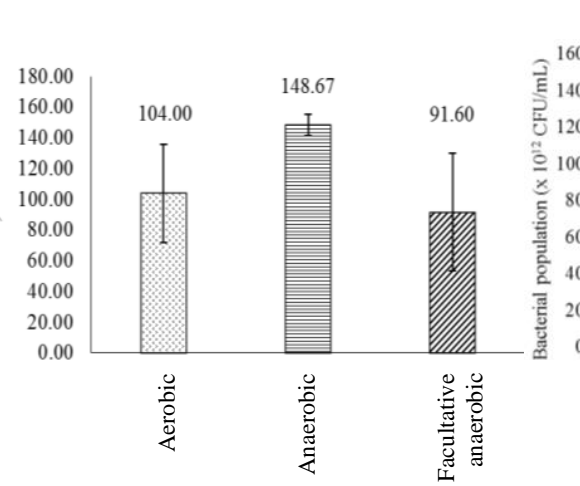

B

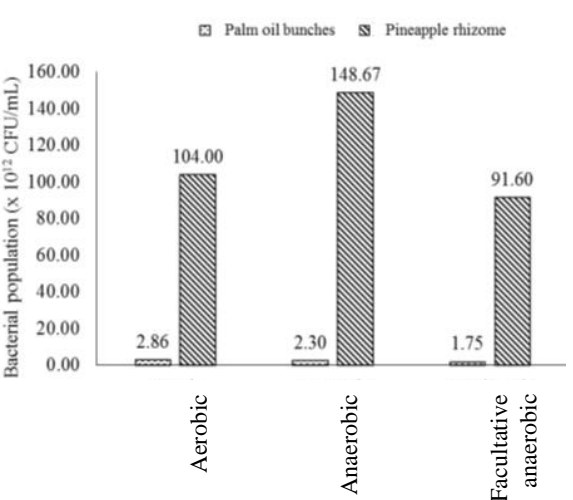

C

Figure 2. Bacterial population within liquid organic fertilizer. A. Total bacterial population within liquid organic fertilizer developed from palm oil bunches. B. Total bacterial population within liquid organic fertilizer developed from pineapple rhizomes. C. Total bacterial population within liquid organic fertilizer developed both from palm oil bunches and pineapple rhizomes 
Different result was gained from LF which was developed from pineapple rhizomes. In the same days' isolation as LF from palm oil bunches, the highest bacterial population was resulted by anaerobic $\left(148.67 \times 10^{12} \mathrm{CFU}\right.$ $\left.\mathrm{mL}^{-1}\right)$ followed by aerobic $\left(104 \times 10^{12} \mathrm{CFU} \mathrm{mL} \mathrm{mL}^{-1}\right)$ and the lowest population was obtained from facultative anaerobic

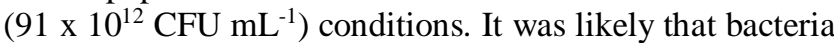
which was in the an aerobic condition can grow and replicate faster than in the aerobic and facultative anaerobic conditions (Fig 2b). On the contrary with palm oil bunches, it was likely that LF developed from pineapple rhizome was dominated by anaerobic bacteria.

Analysis of the total bacterial population within LF which was acquired from palm oil bunches and pineapple rhizomes in every different condition of making LF revealed that bacterial population within LF from palm oil bunches was lower than those developed from pineapple rhizome (Fig 2c). This may have happened because of the different characteristics of palm oil bunches and pineapple rhizomes. Pineapple rhizomes are more lenient than palm oil bunches, and it will be easier for the bacteria to degrade and to utilize organic materials from pineapple rhizomes for their growth than palm oil bunches.

\section{Total bacteria obtained from LF}

Totally, 791 bacterial isolates were successfully obtained from LF developed from both palm oil bunches and pineapple rhizomes. The 301 isolates were successfully obtained from palm oil bunches and 490 isolates from pineapple rhizomes. Among the total isolates, 249 isolates were obtained from aerobic conditions, 242 isolates from anaerobic conditions, and 300 isolates from facultative anaerobic conditions. As for LF created from palm oil bunches, from 301 isolates, 96 isolates obtained from aerobic conditions, 93 isolates from anaerobic conditions and 112 isolates from facultative anaerobic conditions. In the case of 490 bacterial isolates acquired from LF developed from pineapple rhizomes, 153 isolates was gained from aerobic condition, 149 isolates from an aerobic condition and 188 isolates from facultative anaerobic condition (Table 1). Amount of bacteria isolated from aerobic conditions was higher than anaerobic conditions, while amount of bacteria from facultative anaerobic conditions was higher than both formerly conditions. Environmental conditions affected the growth of those bacteria. Aerobic bacteria are the species of bacteria which require oxygen for their basic survival, growth, and the process of reproduction, on the other hand, anaerobic bacteria are the species of bacteria which do not require oxygen for growth. This can be attributed to the fact that aerobic species have the ability to detoxify oxygen. In contrast, anaerobic species lack the ability to sufficiently break down food molecules like their aerobic counterparts. Between the two, there is facultative anaerobic bacteria. These species, which carry out aerobic respiration in the presence of oxygen, also have the tendency to switch over to the process of fermentation in the absence of oxygen. In other words, facultative bacteria are capable of adapting to a range of conditions (Pelczar et al. 2001).

\section{Total isolates of phosphate solubilizing bacteria}

According to the study, phosphate solubilizing bacteria (PSB) was found in the isolates (Figures 3 and 4). From 301 isolates of LF developed by palm oil bunches, 166 isolate $(55.15 \%)$ showed capability to solubilize phosphate and 135 isolates $(44.85 \%)$ did not show any capability as PSB. As for 166 isolates of PSB, 67 isolates were obtained from aerobic conditions, 38 isolates from anaerobic conditions, and 61 isolates from facultative anaerobic conditions. In the case of the 135 isolates which were not PSB, 29 isolates were gained from aerobic conditions, 55 isolates from anaerobic conditions and 51 isolates from facultative anaerobic conditions (Table 2). Media used to grow PSB was Pikovskaya's agar.

As for 490 isolates acquired from pineapple rhizomes, 269 isolates $(54.90 \%)$ had capability to solubilize phosphate, meanwhile, the other 221 isolates $(45.10 \%)$ did not show any capability to solubilize phosphate. Among 269 isolates of PSB, 85 isolates originated from aerobic conditions, 83 isolates from anaerobic conditions, and 101 isolates from facultative anaerobic conditions. From 221 isolates which were not PSB, 68 isolates were isolated from aerobic condition, 66 isolates from anaerobic conditions and 87 isolates from facultative anaerobic conditions (Table 2). Total isolates PSB found either in the palm oil bunches or pineapple rhizomes in the facultative anaerobic condition were higher than aerobic or anaerobic condition. It was likely alternate condition between aerobic and an aerobic was more favorable for the bacteria to grow properly. Aerobic bacteria make energy with oxygen, while anaerobic bacteria make energy without oxygen. They do this in one of two ways, either through lactic acid or alcoholic fermentation. During lactic acid fermentation, cells use a molecule called NADH to take electrons from glucose. The NADH uses the energy stored in the electrons to make ATP, and convert glucose to pyruvate. This process is called glycolysis and is the first step in all forms of cellular respiration. In lactic acid fermentation, the next step is to pyruvate to lactic acid, while, in alcoholic fermentation pyruvate to ethanol (Campbell and Reece 2007).

Table 1. Bacterial isolates obtained from liquid organic fertilizer

\begin{tabular}{|c|c|c|c|}
\hline \multirow{2}{*}{$\begin{array}{l}\text { Conditions of making } \\
\text { liquid organic } \\
\text { fertilizer (LF) }\end{array}$} & \multicolumn{2}{|c|}{ Basic ingredients } & \multirow{2}{*}{$\begin{array}{c}\text { Total } \\
\text { bacterial } \\
\text { isolates }\end{array}$} \\
\hline & $\begin{array}{l}\text { Palm oil } \\
\text { bunches }\end{array}$ & $\begin{array}{c}\text { Pineapple } \\
\text { rhizomes }\end{array}$ & \\
\hline Aerobic & 96 & 153 & 249 \\
\hline Anaerobic & 93 & 149 & 242 \\
\hline Facultative anaer & 112 & 188 & 300 \\
\hline Total bacterial isolates & 301 & 490 & 791 \\
\hline
\end{tabular}

Table 2. Total phosphate solubilizing bacteria

\begin{tabular}{lcccc}
\hline $\begin{array}{l}\text { Conditions of making } \\
\text { liquid organic fertilizer }\end{array}$ & \multicolumn{4}{c}{ Basic Ingredients } \\
(LF) & Palm oil bunches & $\begin{array}{c}\text { Pineapple } \\
\text { rhizomes }\end{array}$ \\
& PSB & Non PSB & PSB & Non PSB \\
\hline Aerobic & 67 & 29 & 85 & 68 \\
Anaerobic & 38 & 55 & 83 & 66 \\
Facultative anaerobic & 61 & 51 & 101 & 87 \\
Total bacterial isolates & 166 & 135 & 269 & 221 \\
\hline
\end{tabular}





Figure 3. Phosphate solubilizing bacteria from the extraction of pineapple rhizome that form clear zones under: A. Aerobic, B. Anaerobic, C. Facultative anaerobic conditions, D. Do not form clear zones on Pikovskaya's media 7 days after inoculation


Figure 4. Phosphate solubilizing bacteria from the extraction of palm oil bunches that form clear zones under: A. Aerobic, B. Anaerobic, C. Facultative anaerobic conditions, D. Do not form clear zones on Pikovskaya's media 7 days after inoculations

Table 3. Capability of the bacterial isolates to solubilize phosphate

\begin{tabular}{lcccccc}
\hline \multirow{2}{*}{ Phosphate solubilizing capability } & \multicolumn{2}{c}{ Palm oil bunches } & \multicolumn{2}{c}{ Pineapple rhizomes } \\
& Aerobic & Anaerobic & $\begin{array}{c}\text { Facultative } \\
\text { anaerobic }\end{array}$ & Aerobic & $\begin{array}{c}\text { Facultative } \\
\text { anaerobic }\end{array}$ \\
\hline Very low & 19 & 19 & 22 & 36 & 54 & 45 \\
Low & 26 & 9 & 20 & 34 & 23 & 27 \\
Medium & 13 & 7 & 14 & 12 & 6 & 14 \\
High & 4 & 3 & 3 & 2 & 0 & 12 \\
Very high & 5 & 0 & 2 & 85 & 83 & 101 \\
Total bacterial isolates & 67 & 38 & 61 & & \\
\hline
\end{tabular}

The chosen isolates of phosphate solubilizing bacteria

Among all the isolates obtained from palm oil bunches which were had capability to solubilize phosphate $(\mathrm{P})$, most of the isolates had very low capability to solubilize $\mathrm{P}$ and only small number isolates had high or very high capability to solubilize P. Those were 60 isolates (19 isolates from aerobic condition, 19 isolates from anaerobic condition and 22 isolates from facultative anaerobic condition) had very low capability, 55 isolates (26 isolates from aerobic condition, 9 isolates from anaerobic condition and 20 isolates from facultative anaerobic condition) had low capability, 34 isolates (13 isolates from aerobic condition, 7 isolates from anaerobic condition and 14 isolates from facultative anaerobic condition) had medium capability, 10 isolates (4 isolates from aerobic condition, 3 isolates from anaerobic condition and 3 isolates from facultative anaerobic condition) had high capability and only 7 isolates (5 isolates from aerobic condition, 2 isolates from facultative anaerobic condition and none from anaerobic condition) had very high capability to solubilize P (Table 3).

In this study, we collected very high capability isolates of PSB as the chosen isolates. In total, 11 chosen isolates were selected from LF developed from both palm oil bunches ( 7 isolates) and pineapple rhizomes (4 isolates) (Table 4). 
Table 4. The chosen phosphate solubilizing bacterial isolates

\begin{tabular}{llll}
\hline Name of isolates & $\begin{array}{l}\text { Condition of } \\
\text { making } \\
\text { liquid } \\
\text { organic } \\
\text { fertilizer }\end{array}$ & $\begin{array}{l}\text { Basic } \\
\text { ingredients } \\
\text { of liquid } \\
\text { organic } \\
\text { fertilizer }\end{array}$ & $\begin{array}{l}\text { Index } \\
\text { capability } \\
\text { to } \\
\text { solubilized } \\
\text { phosphate }\end{array}$ \\
\hline A. Sa (1) 50.10 PKr & Aerobic & $\begin{array}{l}\text { Palm oil } \\
\text { bunches }\end{array}$ & 4.87 \\
A. Sa (3) 50.8 PKr & & & 4.76 \\
A. Sa (2) 50.8 P & & & 4.74 \\
A.S(2)50.8 PKR & & & 4.35 \\
A.S(3)50.8 Pkr & & & 4.72 \\
& Facultative & & 4.54 \\
S.S (2) 50.8 PKr & anaerobic & & 4.19 \\
S.S(1)50.8PKR & Aerobic & Pineapple & 4.27 \\
A.N(1)100.10PKR & & & 5.03 \\
& Facultative & & 4.24 \\
S.N(3)50.12P & anaerobic & & 4.08 \\
S.N(2)50.12P & & & \\
S.N(1)50.12P & & & \\
\hline
\end{tabular}

As for bacterial isolates gained from pineapple rhizomes which were showed capability as PSB, same as those on palm oil bunches, most of the isolates had very low capability to solubilize phosphate and only small number which produced high or very high capability as PSB. In detail, 135 isolates (36 isolates from aerobic condition, 54 isolates from anaerobic condition and 45 isolates from facultative anaerobic condition) had very low capability to solubilize P, 84 isolates (34 isolates from aerobic condition, 23 isolates from anaerobic condition and 27 isolates from facultative anaerobic condition) had low capability to solubilize P, 32 isolates (12 isolates from aerobic, 6 isolates from anaerobic and 14 isolates from facultative anaerobic conditions) had medium capability to solubilize P, 14 isolates ( 2 isolates from aerobic condition, 12 isolates from facultative anaerobic conditions and none from anaerobic condition) had high capability to solubilize phosphate, 4 isolates ( 1 isolate from aerobic condition, 3 isolates from facultative anaerobic condition and none from anaerobic condition) produced very high capability as PSB (Table 3). The capability as PSB would affect the availability of soil phosphorus for plant growth. Phosphate Solubilizing Bacteria stimulates plant growth through enhanced P nutrition (Tomar et al. 1993; Whitelaw et al. $1999)$, increasing the uptake of nitrogen $(\mathrm{N})$, phosphate $(\mathrm{P})$, potassium $(\mathrm{K})$, and iron $(\mathrm{Fe})$ (Biswas et al. 2000).

The isolates from LF created from palm oil bunches produced clear zone area on Pikovskaya's media were in the index range of 4.27 to 4.87 . Those isolates were A. Sa (1) $50.10 \mathrm{PKr}$, A. Sa (3) $50.8 \mathrm{PKr}$, A. Sa (2) $50.8 \mathrm{P}$, A.S(2)50.8 PKR, A.S(3)50.8 Pkr (obtained from aerobic condition), S.S (2) 50.8 PKr, S.S(1)50.8 PKR (obtained from facultative anaerobic condition). As for isolates from LF developed from pineapple rhizomes, they produced clear zone area on Pikovskaya's media were between 4.19 $\mathrm{cm}^{2}$ to $5.03 \mathrm{~cm}^{2}$. The isolates were A.N(1)100.10PKR (obtained from aerobic condition), S.N(3)50.12P,
S.N(2)50.12P and S.N(1)50.12P (obtained from facultative anaerobic condition).

This research findings of isolates of PSB from palm oil bunches and pineapple rhizomes that have high capability to solubilize $\mathrm{P}$, therefore, it will make a chance for phosphorus that is fixed in the soil to become available to plants. Those PSB will have capacity to convert inorganic unavailable phosphorus form to soluble forms $\mathrm{HPO}_{4}{ }^{2-}$ and $\mathrm{H}_{2} \mathrm{PO}_{4}$-through the process of organic acid production, chelation and ion exchange reactions (Khan et al. 2007). In the future, the use of PSB in agricultural practice would decline the high cost of manufacturing phosphate fertilizers as well as they will also mobilize insoluble phosphorus in the fertilizers and soils (Alori et al. 2017; Zaidi et al. 2010; Banerjee et al. 2010). Moreover, the use of PSB is considered as an environmental-friendly alternative to further applications of chemical-based $\mathrm{P}$ fertilizers (Alori et al. 2017).

In conclusion, microbial population in the liquid organic fertilizer (LF) developed from palm oil bunches (PB) was lower than those from pineapple rhizomes (PR). Similarly, collected isolates from $\mathrm{PB}$ has lower index capability as PSB compared to PR. Although, some isolates either from PB or PR did not have capability as PSB. From the study, 11 chosen isolates (from PB was 7 isolates and from PR was 4 isolates) were selected as PSB and will be used for further study to develop LF from PB and PR.

\section{ACKNOWLEDGEMENTS}

We would like to thank the University of Lampung (Unila), Indonesia through LPPM Unila for providing Hibah Professor DIPA BLU funds year 2018 on behalf of Prof. Dr. Dermiyati, Dr. Radix Suharjo, and Dr. Mareli Telaumbanua as well as Faculty of Agriculture, Unila for the permission to use research facilities. Thanks also to PT. GGPC (Great Giant Pineapple Co.) for supplying pineapple rhizomes and PTPN VII for supplying palm oil bunches.

\section{REFERENCES}

Alori ET, Glick BR, Babalola OO. 2017. Microbial phosphorus solubilization and its potential for use in sustainable agriculture. Front Microbiol 8: 971. DOI: 10.3389/fmicb.2017.00971

Atlas RM. 2010. Handbook of Microbiological Media. CRC Press, London.

Banerjee S, Palit R, Sengupta C, Standing D. 2010. Stress induced phosphate solubilization by Arthrobacter sp. and Bacillus sp. isolated from tomato rhizosphere. Aust J Crop Sci 4(6): 378-383.

Biswas JC, Ladha JK, Dazzo FB. 2000. Rhizobia inoculation improves nutrient uptake and growth of lowland rice. Soil Sci Soc Amer J 64: 1644-1650.

Campbell NA, Reece JB. 2007. Biology. 8th ed. Pearson Publisher, New York.

De Kogel WJ. 2019. Sustainable solutions for diseases and pests in crop. Wageningen University and Research, Wageningen.

Ingle KP, Padole DA. 2017. Phosphate solubilizing microbes: An overview. Int J Curr Microbiol App Sci 6 (1): 844-852.

Khan MS, Zaidi A, Wani PA. 2007. Role of phosphate solubilizing microorganisms in sustainable agriculture- A review. Agronomy for 
Sustainable Development, Springer Verlag/EDP Sciences/INRA 27 (1): $29-43$.

Kucey RMN, Janzen HH, Legget ME. 1989. Microbial mediated increases in plant-available phosphorus. Adv Agron 42: 199-228.

Matos ADM, Gomes ICP, Nietsche S, Xavier A, Gomes WS, Neto JADS, and Pereira MCT. 2017. Phosphatase solubilization by endophytic bacteria isolated from banana trees. Anais da Academia Brasileira de Ciencias 89(4): 2945-2954.

Muralikrishna IV, Manickam V. 2017. Environmental management Science and engineering foriIndustry. Butterworth-Heinemann, Oxford. DOI: 10.1016/B978-0-12-811989-1.00016-6.

Nguyen C, Yan W, Le Tacon F, Lapeyrie F. 1992. Genetic variability of phosphate solubilizing activity by monocaryotic and dicaryotic mycelia of the ectomycorrhizal fungus Laccaria bicolor (Maire) P.D. Orton. Plant and Soil 143: 193-199. DOI: 10.1007/bf00007873.

Panhwar QA, Jusop S, Naher UA, Othman R, Razi MI. 2013. Application of potential phosphate-solubilizing bacteria and organic acids on phosphate solubilization from phosphate rock in aerobic rice. Sci World J 2013: 272409. DOI: 10.1155/2013/272409

Pelczar Jr MJ, Chan ECS, Krieg NR. 2001. Microbiology. 5th ed. McGraw Hill Book Company, New York.

Rina MI, Lestari RP, Rahmayani ED, Asan M, Astriani M. 2017. Study of phosphate solubilizing and IAA-producing bacteria from extract of local microorganism of bintaro fruit (Cerbera manghas L.). Jurnal Florea 4(2): 11-21. [Indonesian]

Seshadri S, Ignacimuthu S, Lakshminarsimhan C. 2002. Variations in heterotrophic and phosphate solubilizing bacteria from Chennai, southeast coast of India. Indian J Mar Sci 31 (1): 69-72.
Salmina. 2016. Study of the utilization of oil palm empty fruit bunches waste by the community in Jorong Koto Sawah Nagari Ujung Gading, Lembah Melintang Districts. Jurnal Spasial 3 (2): 33-40. [Indonesian]

Shrivastava M, Srivastava PC, D’Souza SF. 2018. Phosphate-solubilizing microbes: diversity and phosphates solubilization mechanism. In: Meena VS (ed.). Role of Rhizospheric Microbes in Soil. Springer Nature Singapore Pte Ltd., Singapore.

Subba Rao NS. 1993. Biofertilizer in Agriculture and Forestry. International Science Publisher, New York.

Telaumbanua M, Dermiyati, Suharjo R. 2019. Design a stirrer and aerator system for automatic mol production from palm oil and pineapple waste using aerobic, semi aerobic, anaerobic methods. Jurnal Teknik Pertanian Lampung 8 (4): 234-242. [Indonesian].

Tomar SS, Pathan MA, Gupta KP, Khandkar UR. 1993. Effect of phosphate solubilizing bacteria at different levels of phosphate on black gram (Phaseolus mungo). Indian J Agron 38: 131-133.

Whitelaw MA, Harden TJ, Helyar KR. 1999. Phosphate solubilization in solution culture by the soil fungus Penicillium radicum. Soil Biol Biochem 32: 655-665

Whitelaw MA. 2000. Growth promotion of plants inoculated with phosphate solubilizing fungi. Adv Agron 69: 99-151.

Zaidi A., Ahemad M., Oves M., Ahmad E., Khan M.S. 2010. Role of phosphate-solubilizing bacteria in legume improvement. In: Khan MS, Musarrat J, Zaidi A (eds). Microbes for Legume Improvement. Springer, Vienna. 